\title{
PEMANFAATAN LIMBAH TAMBAK IKAN UNTUK BUDIDAYA CACING TANAH Lumbricus rubellus
}

\author{
Andi Rahmad Rahim \\ Dosen Program Studi Akuakultur, Fakultas Pertanian, Universitas Muhammadiyah Gresik \\ Mamat.perikanan@gmail.com; +6285255518547
}

\begin{abstract}
Pond waste treatment is noteworthy, because this is a standard of production success and also one form of cultivation that is responsible for environmental sustainability. This pond waste will be used as a medium for cultivating earthworms. The plan for the implementation of the Community Partnership Program (CPP) is in the village of Pangkah Wetan, Kecamatan Ujungpangkah, Kabupaten Gresik, which is a village where almost all residents live as shrimp and milkfish farmers. The purpose of implementing CPP activities is; 1 . Increase knowledge of shrimp and milkfish farmers to manage waste; 2 . Increasing the knowledge of farmers regarding the use of ponds as a medium for cultivating earthworms that can be applied in the form of organic fertilizer and alternative feed. The methods used are lecture and discussion methods, technology transfer and demonstration methods. Through coaching in the PKM program, it is expected that shrimp and milkfish pond waste management will be able to protect and preserve the environment of the pond waters, so that the farmers will benefit because it can reduce the purchase costs of inorganic chemical fertilizers and artificial feed, even benefit from the cultivation of earthworms.
\end{abstract}

Keywords: earthworms; Pond Waste; alternative feed; organic fertilizer.

\begin{abstract}
ABSTRAK
Pengolahan limbah tambak hal yang patut diperhatikan, karena ini menjadi standar keberhasilan produksi dan juga salah satu bentuk budidaya yang bertanggung jawab terhadap kelestarian lingkungan. Limbah tambak ini akan dimanfatkan sebagai media budidaya cacing tanah. Rencana Lokasi pelaksanaan Program Kemitraan Masyarakat (PKM) adalah di Desa Pangkah Wetan, Kecamatan Ujungpangkah, Kabupaten Gresik, merupakan desa yang hampir seluruh warganya bermata pencaharian sebagai petambak udang dan bandeng. Tujuan pelaksanaan kegiatan PKM adalah; 1. Meningkatkan pengetahuan para petambak udang dan bandeng untuk mengelola limbah; 2 . Meningkatkan pengetahuan petambak mengenai pemanfaatan limbak tambak sebagai media budidaya cacing tanah yang dapat diaplikasikan dalam bentuk pupuk organik dan pakan alternatif. Metode yang digunakan adalah metode ceramah dan diskusi, transfer teknologi dan demonstrasi cara.Melalui pembinaan dalam program PKM, diharapkan pengelolaan limbah tambak udang dan bandeng akan dapat melindungi dan menjaga kelestarian lingkungan perairan tambak, sehingga para petambak akan diuntungkan karena dapat mengurangi biaya pembelian pupuk kimia anorganik dan pakan buatan, bahkan mendapat keuntungan dari hasil budidaya cacing tanah.
\end{abstract}

Kata Kunci : Cacing tanah ; Limbah Tambak; pakan alternatif ; pupuk organik. 


\section{PENDAHULUAN}

Gresik dikenal sebagai penghasil dan menjadi rujukan perikanan tambak udang dan tambak bandeng di Jawa Timur, Gresik menduduki peringkat pertama untuk perikanan tambak udang, setelah itu disusul sidoarjo diperingkat ke dua.Semakin tinggi produksi hasil tambak berdapak terhadap beban limbah yang dihasilkan.Untuk mengurangi dampak limbah tambak, saat ini telah dikembangkan penerapan teknologi super intensif IPAL (Instalasi Pengelolaan Air Limbah).Upaya yang dilakukan dalam penerapan IPAL dengan melakukan pembangunan tandon air limbah yang terdiri dari kolam pengendapan, oksigenasi, biokonversi dan penampungan (Ahmad, 2016).

Pengelolaan limbak tambak udang superintensif terdiri dari empat bagian. Membuat kolam pengendapan tempat membuang air limbah pertama kali agar kadar TSS (total suspended solid) yang sangat tinggi dan bau busuk dari $\mathrm{H}_{2} \mathrm{~S}$ turun dan sisa endapan dapat dibuat pupuk.Dari kolam tersebut, sisa air limbah masuk ke kolam oksigenasi untuk menaikkan oksigen dan menurunkan BOD (kebutuhan oksigen biologis).Sisanya masuk ke kolam biokonversi untuk mengubah nutrien yang bisa menyebabkan eutrofikasi menjadi bermanfaat bagi organisma lain, baru sisa terakhir ini masuk ke kolam penampungan untuk selanjutnya dibuang ke laut (Ahmad, 2016; Fahrur dkk, 2016).Pengolahan limbah tambak hal yang patut diperhatikan, karena ini menjadi standar keberhasilan produksi dan juga salah satu bentuk budidaya yang bertanggung jawab terhadap kelestarian lingkungan.

Dari hasil analisis usaha budidaya tambak secara intensif dan semi intensif menunjukkan bahwa biaya produksi tertinggi adalah pakan yang berkisar $44 \%$. Tingginya biaya pakan antara lain disebabkan karena FCR (rasio konversi pakan) cenderung meningkat. Dampak lain dari FCR yang tinggi adalah menyebabkan air media dapat tercemar akibat akumulasi sisa pakan dan ekskresi ammonia dengan cepat. Dalam hal ini diperlukan cara penanggulangan baik melalui pengurangan akumulasi sisa pakan maupun pengurangan ekskresi. Pengurangan ransum pakan secara periodik (pemuasaan) diduga merupakan salah satu cara yang dapat digunakan untuk menurunkan laju metabolisme maupun akumulasi sisa pakan. Pada hewan air, penurunan metabolisme dapat memberikan dua keuntungan yaitu penurunan konsumsi makanan dan pengurangan pencemaran air media melalui pengurangan ekskresi ammonia (Mansyur dkk, 2011).

Permasalahan khusus yang terjadi di Desa Pangkah Wetan Kecamatan Ujung Pangkah Kabupaten Gresik yaitu dalam proses budidaya ikan dan udang di Tambak penggunaan pakan buatan dan pupuk anorganik dengan sistim intensif diperlukan dengan jumlah yang besar, sisa pakan dan pupuk anorganik yang berlebihan di Tambak budidaya menyebabkan penurunan produktivitas Tambak sehingga mempengaruhi kualitas dan kuantitas yang akan menurun dari budidaya ikan dan udang di Tambak. Kemudian biaya untuk penggunaan pakan dan pupuk anorganik sangat besar, sehingga dari Program Kemitraan Masyarakat (PKM) ini berinovasi untuk mengelola limbah Tambak untuk budidaya cacing tanah dalam menghasilkan pupuk organik (sisa budidaya cacing tanah/vermikompos) dan pakan alternatif berupa (cacing tanah Lumbricus rubellus).

\section{TINJAUAN PUSTAKA}

Limbah dari tambak ini berupa sisa pakan dan sisa pupuk yang telah difermentasi kemudian dimanfaatkan dalam budidaya cacing tanah untuk menghasilkan pakan tambahan dan pupuk organik.Cacing tanah (Lubricus rubellus) adalah makanan alami dengan sumber protein tinggi sebagai bahan pakan alternatif.Budidaya cacing tanah relatif mudah, efisien dan murah, dimana untuk membudidayakan cacing ini hanya 
dibutuhkan suatu media berupa tanah dan kompos. Medium pembiakan yang biasa digunakan antara lain seperti tanah, kotoran sapi, batang pisang lapuk dan limbah organik (Albanell et al, 2008). Sisa media dari budidaya cacing ini selanjutnya dapat dimanfaatkan untuk pupuk (kascing baik untuk tanaman di darat maupun di perairan (Tambak), karena penguraian sampah organik oleh cacing tanah banyak menghasilkan unsur hara yang sangat dibutuhkan bagi organisme budidaya. Vermikomposadalah kompos yang diperoleh dari hasil perombakan bahan-bahan organik yang dilakukan oleh cacing tanah.Vemikompos merupakan campuran kotoran cacing tanah (kascing) dengan sisa media atau pakan dalam budidaya cacing tanah.Oleh karena itu vermikompos merupakan pupuk organik yang ramah lingkungan.Vermikompos mempunyai struktur remah, sehingga dapat mempertahankan kestabilan dan aerasi tanah.Vermikompos mengandung enzim protease, amilase, lipase dan selulase yang berfungsi dalam perombakan bahan organik (Afriyansyah, 2010).

Kecamatan Ujung Pangkah merupakan suatu daerah di Kabupaten Gresik yang penduduknya sebagian besar mempunyai mata pencaharian sebagai petani tambak.Petani tambak dalam usahanya banyak menggunakan pestisida.Penggunaan pestisida merupakan salah satu sumber pencemar yang potensial bagi sumberdaya dan lingkungan perairan.Hampir semua jenis pestisida tidak bersifat selektif dan mempunyai spektrum yang luas sebagai racun sehingga merupakan sumber pencemaran yang potensial khususnya bagi sumberdaya dan lingkungan perairan (Taufik dkk, 2007).Pakan yang digunakan juga dapat menjadi sumber pencemaran perairan yang menyebabkan penurunan produktivitas hasil tambak. Bagi udang, senyawa beracun akibat proses perombakan tumpukan bahan organik dari pakan dan kotoran mengakibatkan turunnya nafsu makan, stres, mudah terserang penyakit dan mengakibatkan kematian. Salah satu penyakit yang tenar di kalangan budidaya udang saat ini, white feses disease (WFD).Limbah tambak berupa unsur organik, biasanya sisa pakan, bisa mengganggu keseimbangan ekosistem pantai. Akumulasi unsur organik bisa meningkatkan populasi alga yang mengganggu komunitas ikan dan mengganngu budidaya lain yang ada di pantai.

\section{METODE}

Metode pelaksanaan dalam membantu masyarakat memahami dampak dari limbah tambak dan pemanfaatannya dilakukan dengan menggunakan metode ceramah dan diskusi. Metode pelaksanaan dalam membantu masyarakat atau kelompok sasaran dalam membantu kemampuan kewirausahaan dilakukan dengan menggunakan model Enterpreneurship Capacity Building (ECB) yaitu dengan cara, memberi wawasan keterampilan dan peluang berusaha budidaya cacing tanah dengan memanfaatkan limbah tambak udang dan bandeng (kewirausahaaan, manajemen usaha produktif, introduksi IPTEK budidaya cacing tanah dan mengenal jaringan pemasaran hasil budidaya cacing tanah melalui teknologi informasi digital).

\section{HASIL DAN PEMBAHASAN}

Hasil yang dicapai dalam Program Kemitraan Masyarakat adalah:

1. Kegiatan koordinasi dan survei lapangan pelaksanaan kegiatan pengabdian. Kegiatan ini merupakan koordinasi awal dengan mitra/kelompok di Kecamatan Ujungpangkah Gresik. Hasil koordinasi dan survei, disepakati kegiatan 2 mitra/kelompok dilaksanakan bimbingan teknis di PAUD Desa Pangkah Wetan Kecamatan Ujungpangkah Kabupaten Gresik. Pelaksanaan praktek langsung kegiatan budidaya cacing tanah dilakukan di rumah bapak Ir. Ahmad Robah, yang memiliki luas pekarangan sesuai dengan persyaratan kegiatan budidaya cacing tanah, yang 
bertempat di Jl. Sitarda Desa Pangkah Wetan Kecamatan Ujungpangkah Kabupaten Gresik.
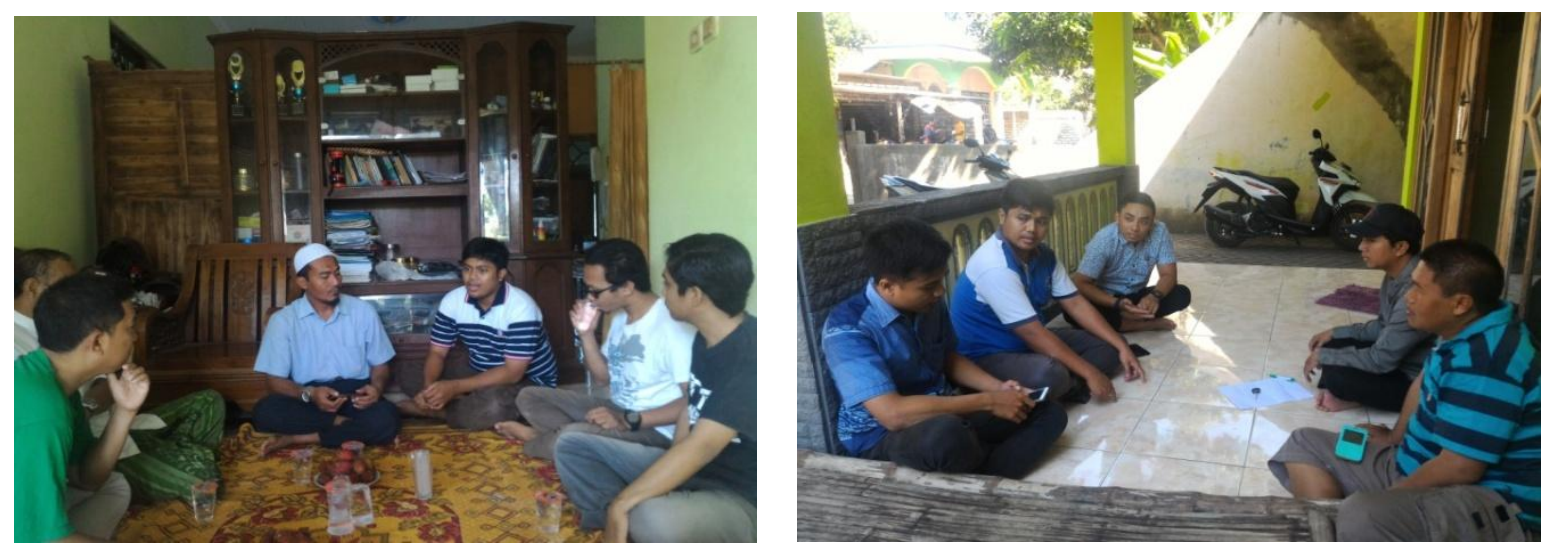

Gambar 1. Koordinasi dengan dua mitra/kelompok Desa untuk pelaksanaan kegiatan pengabdian.
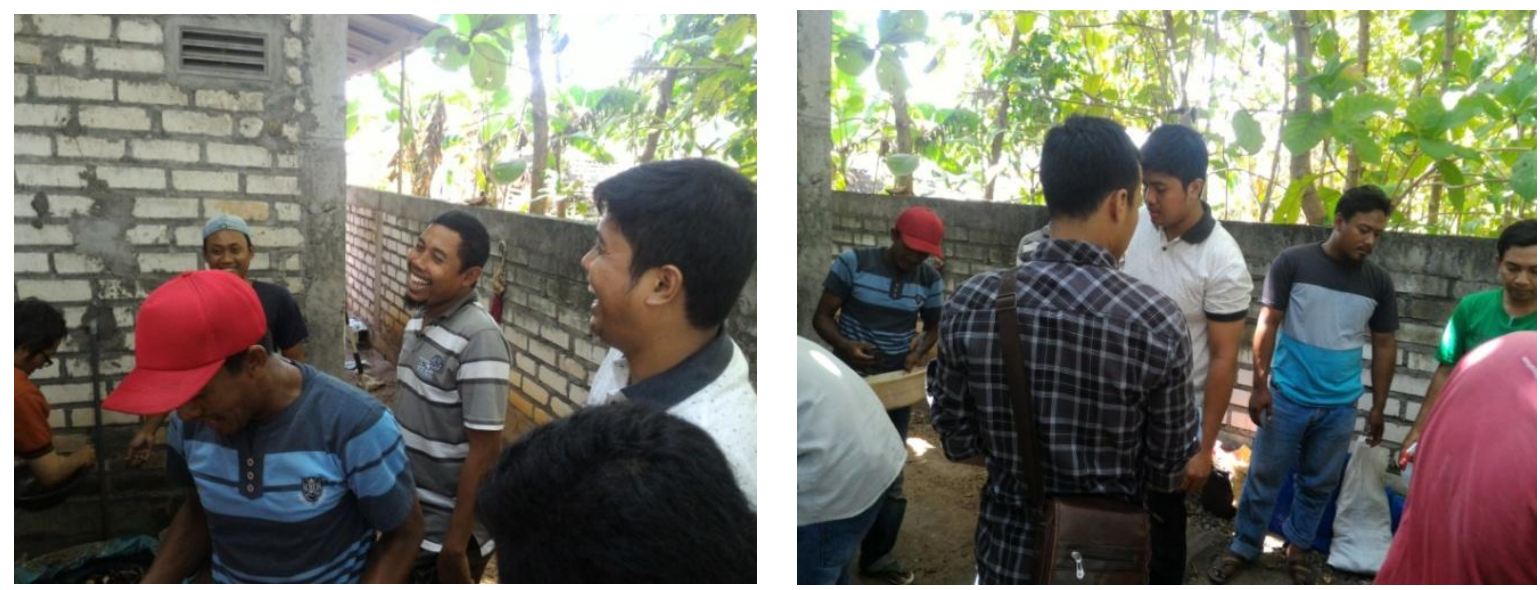

Gambar 2. Survei lokasi tempat pelaksanaan kegiatan budidaya cacing tanah.

2. Penyiapan media budidaya cacing tanah. Media yang digunakan untuk budidaya cacing tanah berupa tanah, kotoran sapi kering, alang-alang, limbah tambak, batang pisang dan indukan cacing tanah. Media yang digunakan berasal dari sekitaran Tambak budidaya ikan dan udang di Kecamatan Ujungpangkah kabupaten Gresik, indukan cacing tanah didapatkan di Kecamatan Sedati Kabupaten Sidoarjo. 

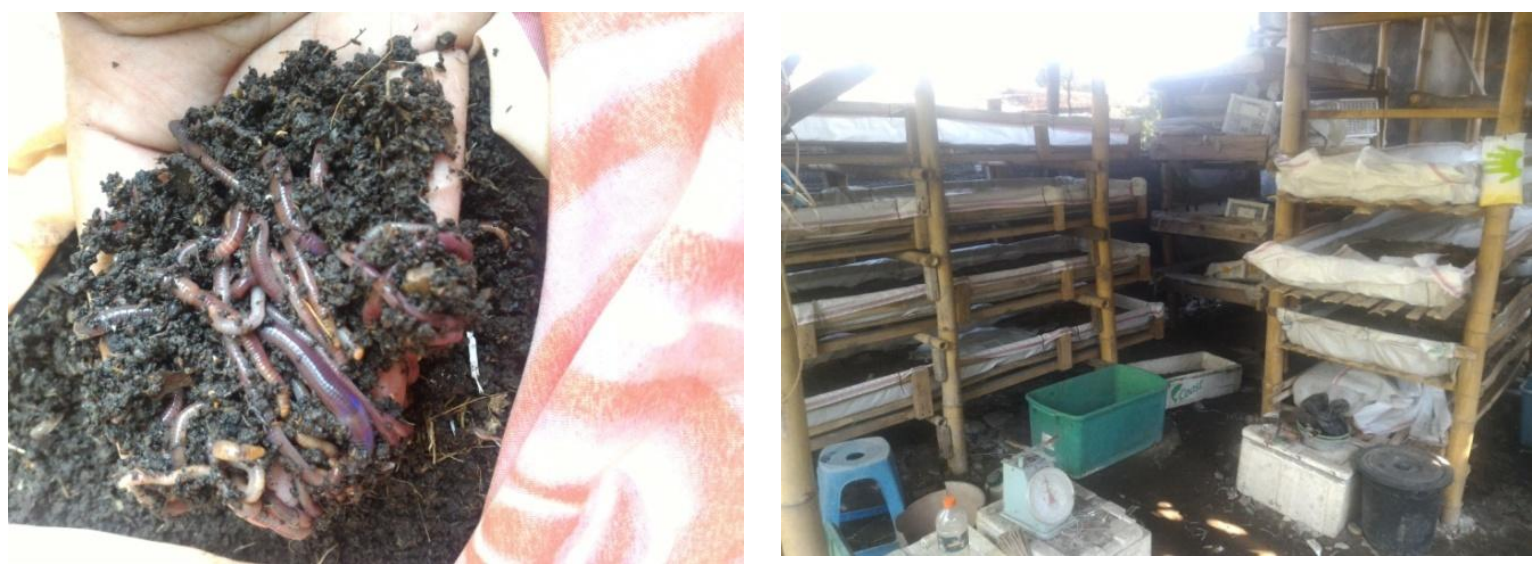

Gambar 3. Indukan cacing tanah (Lumbricus rubellus) yang diambil di Sidoarjo.
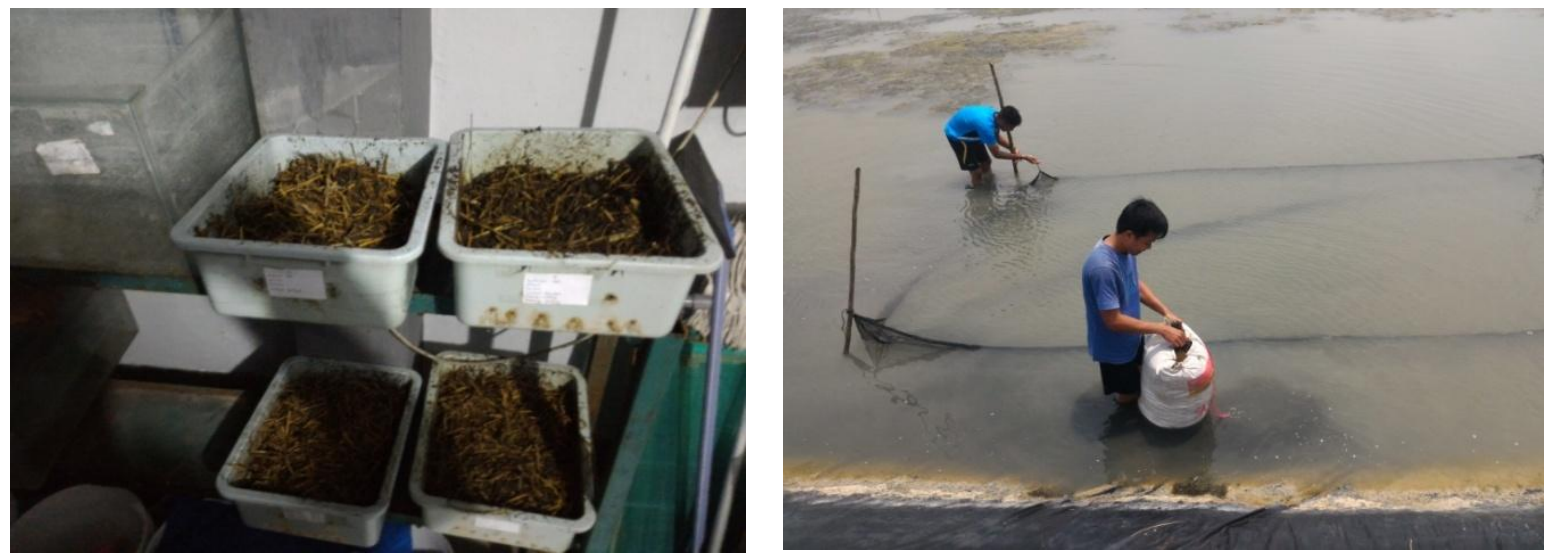

Gambar 4. Media budidaya cacing tanah (batang pisang, alang-alang, kotoran sapi, tanah) dan pengambilan limbah tambak dari sisa budidaya berupa sisa pakan dan pupuk yang mengendap di dasar Tambak.

3. Pelaksanaan bimbingan teknis dan peraktek langsung kegiatan budidaya cacing tanah. Pelaksanaan bimbingan teknis dilaksanakan dengan menyiapkan materi tentang budidaya cacing tanah, penyampaian materi berbasis power point dan video. Pelaksanaan budidaya di lakukan dengan langkah-langkah praktek langsung di lapangan dengan melibatkan mahasiswa program studi budidaya perikanan UMG sebgai pendamping dalam kegiatan budidaya cacing tanah dengan memanfaatkan limbah sekitaran tambak berupa limbah tambak budidaya, alang-alang, batang pisang dan kotoran sapi. Mahasiswa yang dilibatkan sebagai pendamping sebanyak 3 Mahasiswa. 

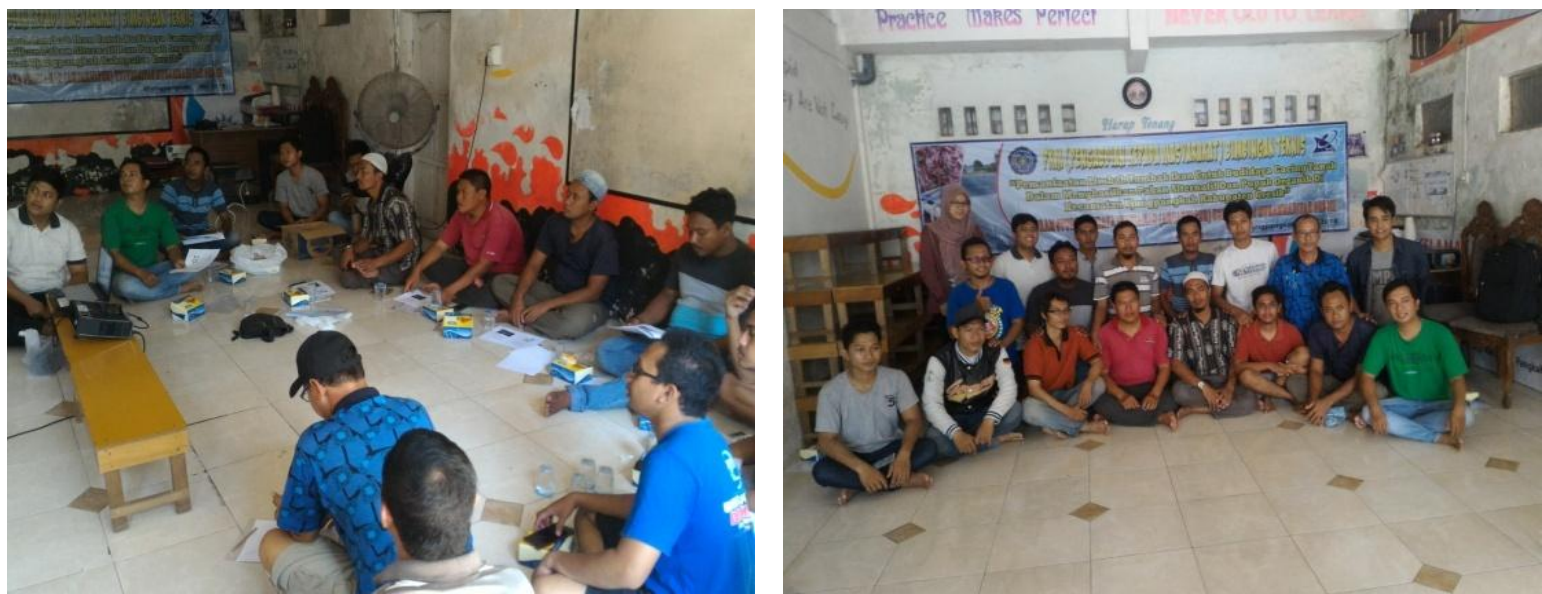

Gambar 5. Bimbingan teknis budidaya cacing tanah di Kecamatan Ujungpangkah, Gresik.
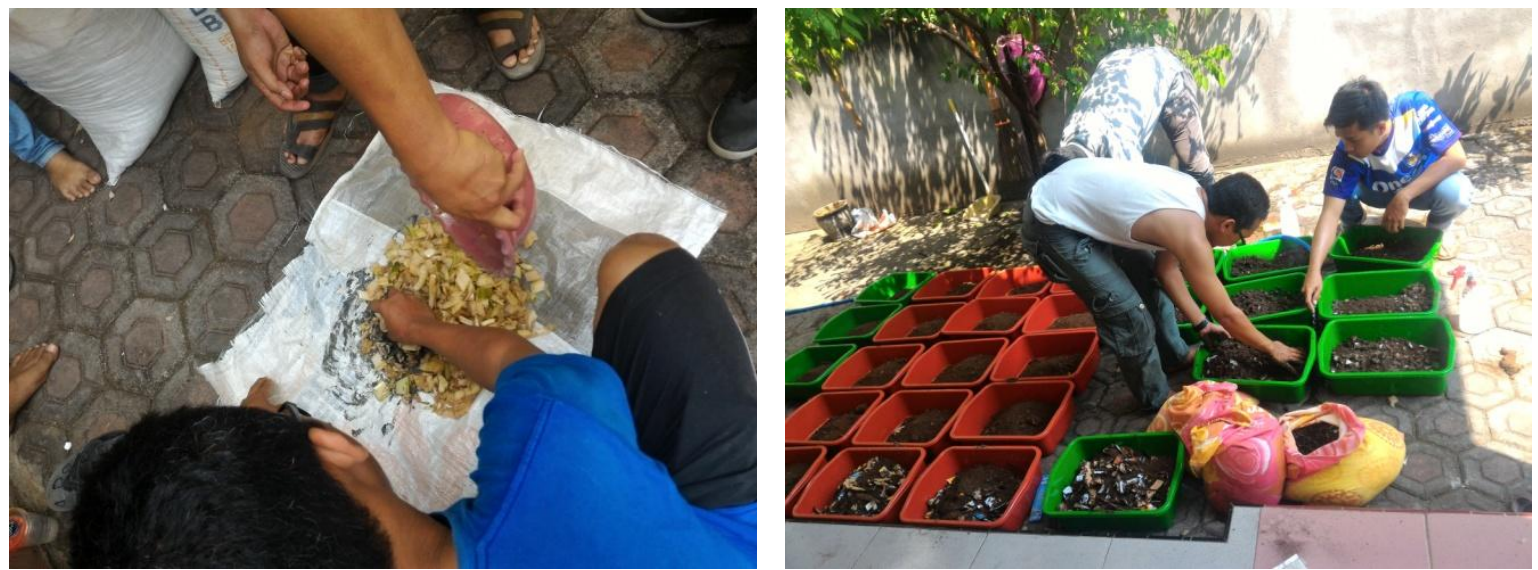

Gambar 6. Pencampuran media budidaya cacing tanah dan di letakkan di dalam baskom plastik.
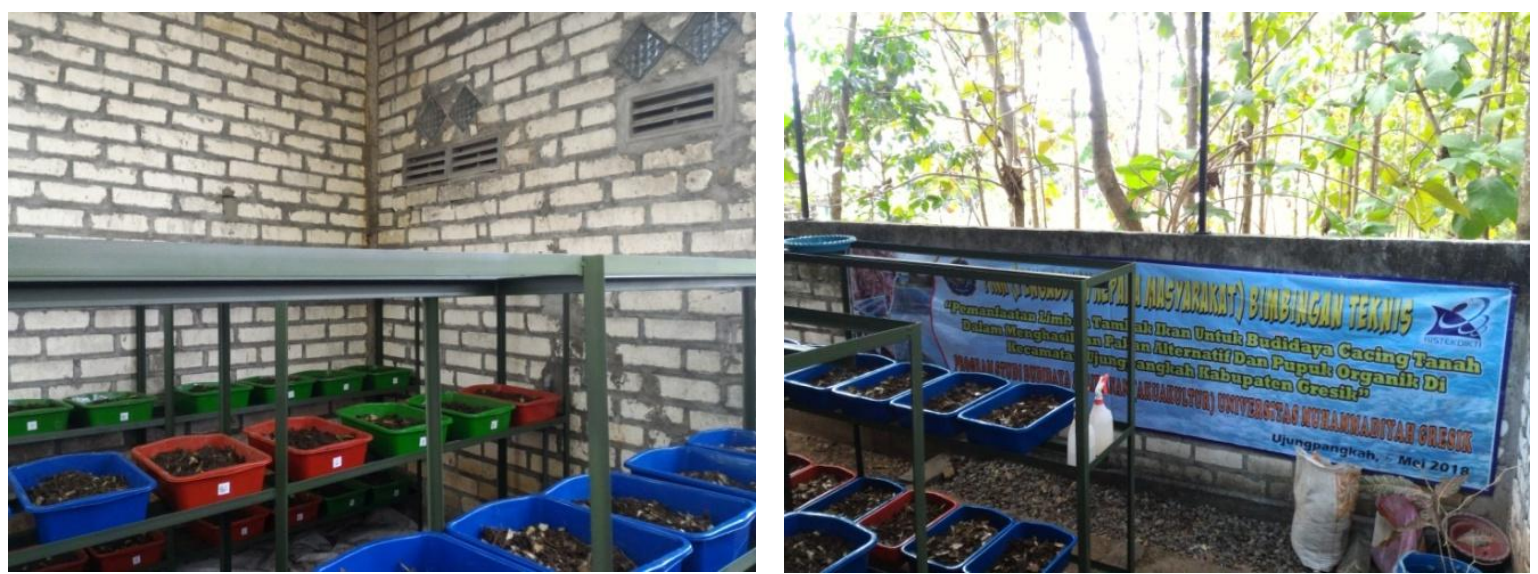

Gambar 7. Peletakkan media budidaya cacing tanah dengan menggunakan sistem rak bertingkat.

4. Monitoring. Kegiatan budidaya cacing tanah ini dimonitoring setiap 7 hari sekali selama 6 bulan (masih berlangsung sampai sekarang) dengan melakukan penyemprotan air pada media untuk menjaga kelembapan media, penggantian dan 
penambahan limbah sebagai pakan cacing tanah, pengadukan media untuk sirkulasi udara.
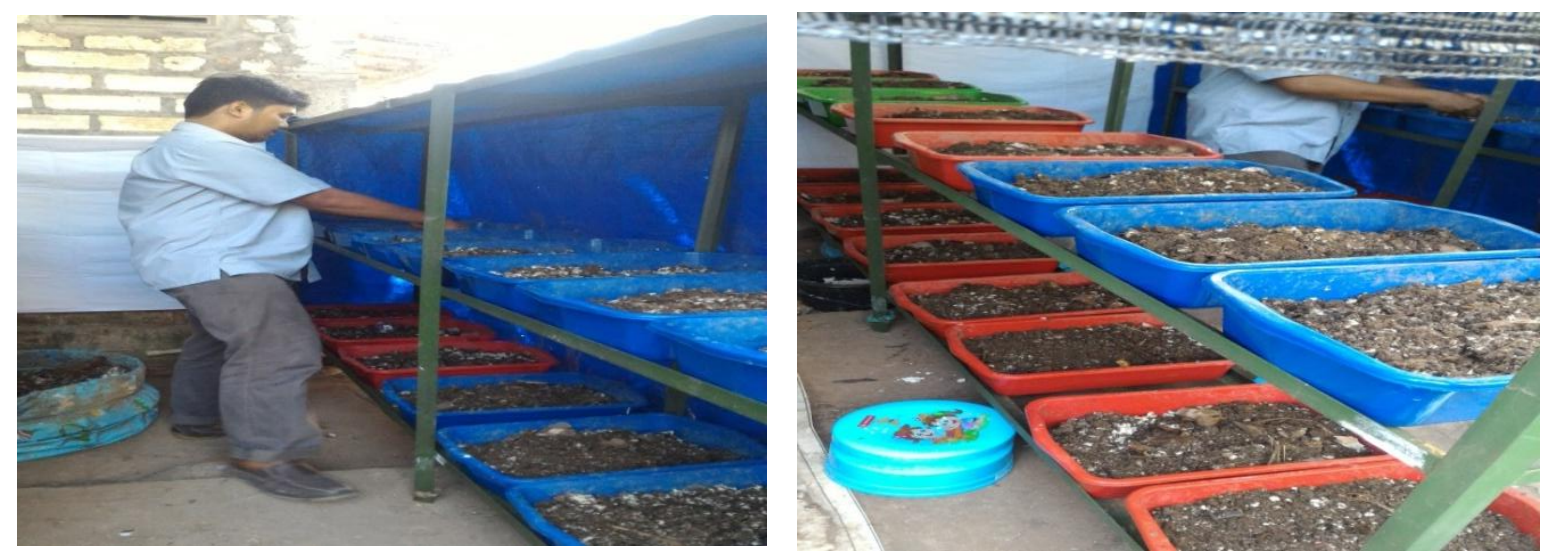

Gambar 8. Pengontrolan budidaya cacing tanah di Kecamatan Ujungpangkah, Gresik.

\section{KESIMPULAN DAN SARAN}

Kegiatan Program Kemitraan Masyarakat (PKM) sudah dilakukan berupa bimbingan teknis dan pelaksanaan langsung kegiatan budidaya cacing tanah di Kecamatan Ujungpangkah, Gresik. Kegiatan ini diawali dengan koordinasi dengan para Mitra dan survei langsung untuk mengetahui lokasi tempat kegiatan budidaya cacing tanah, pengumpulan media - media yang digunakan untuk budidaya cacing tanah yang berupa kotoran sapi, alang - alang, batang pisang dan limbah tambak berupa sisa pakan dan pupuk yang mengendap di dasar Tambak. Setelah itu, dilaksanakan bimbingan teknis dan praktek langsung kegiatan budidaya cacing tanah yang menghadirkan Mahasiswa perikanan UMG sebagai pendamping. Kegiatan ini diharapkan dapat terus dijalankan dan diaplikasikan oleh masyarakat di Kecamatan Ujungpangkah, Kabupaten Gresik pada Tambak budidaya.

\section{UCAPAN TERIMAKASIH}

Penulis menyampaikan terimakasih kepada para Mitra/Kelompok di Kecamatan Ujungpangkah, Gresik atas kesediannya bekerjsama untuk kegiatan Program Kemitraan Masyarakat (PKM) Kemenristek Dikti Tahun 2018.

\section{DAFTAR PUSTAKA}

Afriynsyah, B. 2010. Vermicomposting Oleh Cacing Tanah (Eisenia fetida dan Lumbricus rubellus) Pada Empat Jenis Bedding. Bogor. Pasca Sarjana Institut Pertanian Bogor.

Ahmad, F. 2016. Efektivitas Pengolahan Air Limbah (IPAL) Tambak Udang Super Intensif (Studi Kasus di Desa Punaga, Kabupaten Takalar). Sulawesi Selatan. Universitas Hasanudin.

Albanell E, Plaixats J, Cabrero T. 2008. Chemical Changes during Vermicomposting (Eisenia fetida) of Sheep Manure with Cotton Industrial Waste. Biol Fertil Soils 6 $\square 266-269$.

Fahrur, M., Muhammad, C., Rachman, S. 2016. Erforma Instalasi Pengolah Air Limbah (IPAL) Tambak Udang Vaname Superintensif. FITA Prosiding.

Mansyur, A., Hidayat, S., Suwoyo, Rachmansyah. 2011. Pengaruh Pengurangan Rnasum Pakan Secara Periodik Terhadap Pertumbuhan, Sintasan dan 
Produksi Udang Vaname (Litopenaeus vannamei)Pola Semi-Intensif di Tambak. Sulawesi Selatan. Balai Riset Perikanan Budidaya Air Payau.

Taufik, I., Koesoemadinata, S., Sutrisno, \& Nugraha, A. 2007. Tingkat Akumulasi Residu Pestisida Pertanian di Perairan Tambak. J. Pen. Perik. Indonesia, 9(4): 53-61. 